\title{
4 Recovery of uranium from nuclear conversion plant waste
}

\author{
by M. Potgieter* ${ }^{\star}$, J.C. Barry*, D.J. van der Westhuizen`, and \\ H.M. Krieg†
}

\section{Synopsis}

The ammonium diuranate (ADU) conversion process that was operated at the Nuclear Energy Corporation of South Africa (Necsa) in the past generated a significant amount of waste containing high concentrations of uranium, which can be re-used if the uranium can be recovered in a useful form. To attain this objective, the composition of the waste material and the amounts of impurities present were determined, followed by an investigation into various methods of uranium dissolution. For dissolution, water as well as different acid types and concentrations were investigated, and the efficiency of each method determined in terms of the uranium recovery as well as the extent of impurities extraction. It was found that the waste material was soluble in $\mathrm{HNO}_{3}, \mathrm{H}_{2} \mathrm{SO}_{4}$, and $\mathrm{HCl}$ as well as water, with a maximum uranium extraction of $98 \%$ achieved in $3 \mathrm{M} \mathrm{HNO}_{3}$ in 1 hour at a temperature of $80^{\circ} \mathrm{C}$ without the addition of an oxidizing agent. The thorium impurity content in relation to uranium was reduced from $8.4 \%$ to less than $1 \%$ with all acids investigated, as well as water. The most significant reduction in the total impurity content, from $24.3 \%$ to $10.8 \%$, was observed when using water, although this did not result in the highest uranium extraction.

\section{Keywords}

uranium, nuclear waste, conversion process, dissolution, purification, hydrogen peroxide.
Basically, the ADU conversion process entailed the conversion of ADU to uranium tetrafluoride $\left(\mathrm{UF}_{4}\right)$, which was then converted to uranium hexafluoride $\left(\mathrm{UF}_{6}\right)$ in a fluorine flame reactor (Ponelis, 1989). The final product, thermally stable $\mathrm{UF}_{6}$ gas, was then filtered to remove any foreign particles. Thereafter, the $\mathrm{UF}_{6}$ was frozen out and distilled before being fed to the enrichment plant. Due to the incomplete conversion of $\mathrm{UF}_{4}$ to $\mathrm{UF}_{6}$ in the fluorine flame reactor, a significant amount of solid waste rich in uranium was formed, which accumulated at the bottom of the reactor. The incomplete conversion could have been caused by various factors, including sintering due to the low melting point of $\mathrm{UF}_{4}$, inhomogeneous feed compositions, and the presence of various impurities. A study to determine the effect of alkali metal impurities on the conversion of $\mathrm{UF}_{4}$ to $\mathrm{UF}_{6}$ showed that the presence of these impurities had a significant effect on the sintering of $\mathrm{UF}_{4}$ (Ponelis, 1989).

Owing to the high uranium content, the unreacted material is a nuclear liability and needs to be processed to recover a product that can be re-used in possible future conversion activities while reducing the amount of waste that is currently stored in drums. A search of the literature was undertaken to determine whether similar waste exists elsewhere, and how it is handled. Sasahira et al. (2007) mention an 'ash' that was formed during fluorination of $\mathrm{UO}_{2}$ to $\mathrm{UF}_{6}$, while Ohashi,

* Uranium Chemistry Group, Plasma Technology, Applied Chemistry, Nuclear Energy Corporation of South Africa (Necsa), South Africa.

+ Membrane Technology Group, Chemical Resource Beneficiation (CRB), North-West University (NWU), South Africa.

() The Southern African Institute of Mining and Metallurgy, 2017. ISSN 2225-6253. This paper was first presented at the Hydrometallurgy Conference 2016 'Sustainable Hydrometallurgical Extraction of Metals', 1-3 August 2016, Belmont Mount Nelson Hotel, Cape Town. 


\section{Recovery of uranium from nuclear conversion plant waste}

Murashita, and Nomura (2014) extracted uranium from $\mathrm{UF}_{4}$ residue and $\mathrm{NaF}$ adsorbents originating from conversion activities. It thus became clear that this waste material is unique, in terms of its intrinsic variety in composition as well as the amounts and types of impurities present.

In view of the solvent extraction (SX) process that is used to purify uranium (Kumar et al., 2011), the waste material in its current solid form will have to be dissolved to obtain an aqueous solution containing the desired uranium.

Furthermore, in order to extract uranium successfully using

SX, the fluoride content should be low since fluoride is coextracted by tributyl phosphate (TBP) (Volk, Vakhrushin, and Mamaev, 2000; Coleman, 1966).

It can be assumed that a significant amount of the contained uranium is in the $\mathrm{UF}_{4}$ form, since the waste material was generated in the $\mathrm{UF}_{4}$ to $\mathrm{UF}_{6}$ conversion step in the process, and unreacted material would therefore consist of $\mathrm{UF}_{4}$. For the envisioned SX process, provision should be made for the oxidation of insoluble $U(I V)$ to soluble $U(V I)$ during dissolution, possibly by means of the addition of an oxidizing agent. $\mathrm{UF}_{4}$ can be completely solubilized by direct treatment with concentrated nitric acid $\left(\mathrm{HNO}_{3}\right)$ (Floreancig, 1983, Ohashi, Murashita, and Nomura, 2014). Luk'yanchev and Nikolaev (1963) studied the dissolution of $\mathrm{UF}_{4}$ in sulphuric $\left(\mathrm{H}_{2} \mathrm{SO}_{4}\right)$ and hydrochloric $(\mathrm{HCl})$ acid, and found that the solubility of $\mathrm{UF}_{4}$ increases with increasing $\mathrm{HCl}$ concentration, and reaches a maximum in $\mathrm{H}_{2} \mathrm{SO}_{4}$ at approximately $3 \mathrm{M}$. Ohashi, Murashita, and Nomura (2014) used an oxidizing agent $\left(\mathrm{H}_{2} \mathrm{O}_{2}\right)$ during dissolution of $\mathrm{UF}_{4}$ in $\mathrm{H}_{2} \mathrm{SO}_{4}$ and $\mathrm{HCl}$ as part of a study on the extraction of uranium from fluorine-containing waste. They found that $\mathrm{UF}_{4}$ could be completely dissolved in $1.25 \mathrm{M} \mathrm{HCl}$ or $0.3 \mathrm{M}$ $\mathrm{H}_{2} \mathrm{SO}_{4}$.

The aim of this investigation was, therefore, to dissolve the current waste material and to obtain the highest possible recovery of uranium in solution. Since no reference to similar waste material could be found, and a low solubility was expected due to its sintered nature, the waste material was milled prior to dissolution. The dissolution efficiency was investigated using water as well as different acids $\left(\mathrm{HNO}_{3}\right.$, $\mathrm{H}_{2} \mathrm{SO}_{4}$, and $\mathrm{HCl}$ ) with and without the addition of $\mathrm{H}_{2} \mathrm{O}_{2}$ as an oxidizing agent. Water was included as a washing step prior to dissolution to determine its suitability for removing any water-soluble impurities. Since the waste material is known to contain high levels of fluoride (approx. 20\%), different methods will be investigated for removing fluoride subsequent to dissolution but prior to SX, but this falls beyond the scope of the current study. In this paper the focus is mainly on cations in the waste material with concentrations above 0.5 mass $\%$.

\section{Experimental}

\section{Composition of waste material}

The composition of the waste material was determined, focusing on the uranium $(\mathrm{U})$ content and other major constituents that may ultimately influence the SX-based uranium recovery process. A sample of the waste material was dissolved in nitric acid ( $65 \mathrm{wt} \% \mathrm{HNO}_{3}$ ) in a 1:1 water to acid ratio. The solution was evaporated to dryness and the residue was re-dissolved in $\mathrm{HNO}_{3}$ at the same concentration to achieve complete dissolution, followed by analysis using inductively coupled plasma-optical emission spectrometry (ICP-OES).

\section{Dissolution tests}

Nitric acid $\left(\mathrm{HNO}_{3}, 65 \mathrm{wt} \%\right)$, sulphuric acid $\left(\mathrm{H}_{2} \mathrm{SO}_{4}, 98 \mathrm{wt} \%\right)$, and hydrochloric acid ( $\mathrm{HCl}, 32 \mathrm{wt} \%$ ) were obtained from Merck. The dissolution tests were conducted using $\mathrm{HNO}_{3}$ at concentrations of $3 \mathrm{M}$ and $1 \mathrm{M}, \mathrm{H}_{2} \mathrm{SO}_{4}$ at $2.5 \mathrm{M}$ and $1.25 \mathrm{M}$, and $\mathrm{HCl}$ at $3 \mathrm{M}$ and $1 \mathrm{M}$, as well as ultrapure water.

Experiments were conducted in the absence and presence of $0.4 \mathrm{~mL} \mathrm{H}_{2} \mathrm{O}_{2}$ (30 wt\%, from Merck) as an oxidizing agent to aid the oxidation of insoluble U(IV) to soluble U(VI). For the solubility measurements, a $1 \mathrm{~g}$ sample of the waste material was added to a $100 \mathrm{~mL}$ acid solution and heated to $80^{\circ} \mathrm{C}$ on a hot plate. The temperature was chosen to be high enough to ensure fast reaction kinetics, but low enough to ensure that the solution did not boil, which would cause unwanted loss of solution as well as the evolution of noxious fumes. Each dissolution experiment was continued for 1 hour with continuous stirring using a stirrer bar, to ensure sufficient time for the reaction to proceed, after which the mixture was left to cool to room temperature. The mixture was then centrifuged and decanted to separate the solution from the residue. The residue was washed with distilled water, dried in an oven at $100^{\circ} \mathrm{C}$, and weighed. A sample of each solution and residue was analysed using ICP-OES.

Using the acid with which the highest uranium recovery was attained, a more comprehensive study was subsequently undertaken in which additional acid concentrations were investigated under identical experimental conditions to the screening investigation described above.

\section{Results and discussion}

\section{Composition of waste material}

A rough estimate of the composition of the waste material was determined (data not shown) by X-ray fluorescence (XRF). Based on this data, the cations present at concentrations greater than $0.5 \%$ by mass were determined using ICP-OES. The results are shown in Table I.

Since uranium will be recovered by means of SX, lowering the amount of impurities that may have an influence on the SX process would be an added benefit. From Table I it is clear that Fe $(28.0 \mathrm{mg} / \mathrm{g})$, Th $(44.5 \mathrm{mg} / \mathrm{g})$, and $\mathrm{Ca}$ $(50.0 \mathrm{mg} / \mathrm{g})$ are the main impurity elements in the waste material. Currently, there are no clear specifications for the final product material that would result from recovery of uranium. However, it is envisaged that the product would be re-used in a nuclear conversion plant. Therefore, the ASTM standard for uranium ore concentrate (UOC) can be used to specify the maximum allowed levels of impurities of the final product. These are $1 \%$ for both calcium and iron and $2.5 \%$ for thorium (ASTM, 2013). The focus of the current study was to dissolve the waste material as a preparatory step for future purification by SX, and lowering the levels of these impurities would be a benefit if it can be achieved during this 


\section{Recovery of uranium from nuclear conversion plant waste}

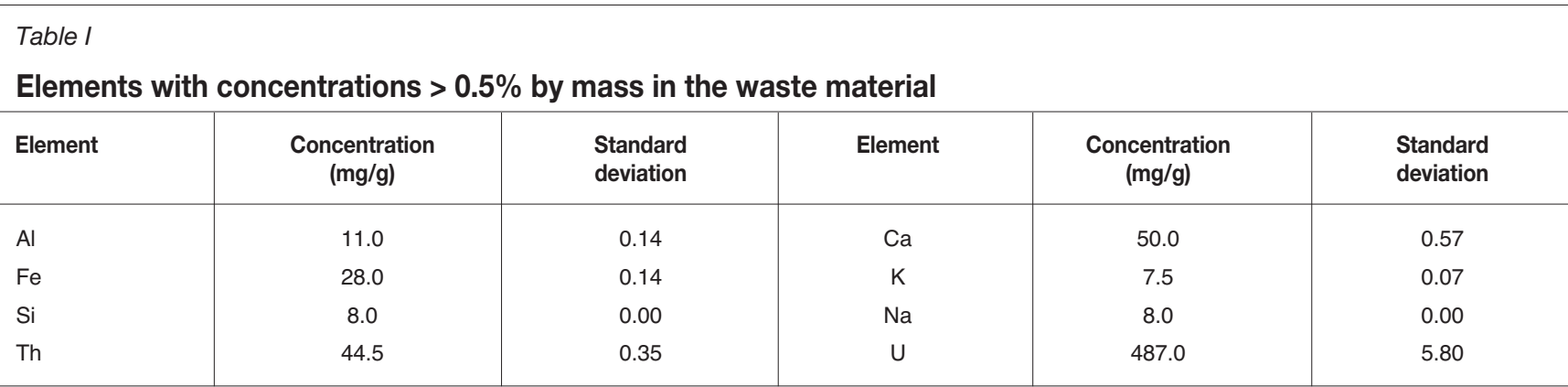

step. To facilitate the discussion on impurities, the content of each impurity was expressed as a percentage of the uranium according to the relationship:

$$
\text { Impurity (i) } \%=\frac{[\mathrm{i}]}{[\mathrm{i}]+[\mathrm{U}]} \times 100
$$

where $\mathrm{i}$ and $\mathrm{U}$ refer to the impurity and uranium respectively. The values are presented in Table II.

As mentioned previously, it can be assumed that most of the impurities originate from the feed material to the conversion process. Accordingly, the high thorium content resulted from the non-volatility of the formed $\mathrm{ThF}_{4}$, which caused it to settle at to the bottom of the flame reactor

\begin{tabular}{|c|c|}
\hline \multicolumn{2}{|c|}{$\begin{array}{l}\text { Table /I } \\
\text { Impurity contents relative to uranium }\end{array}$} \\
\hline Element & Impurity \% \\
\hline $\mathrm{Ca}$ & 9.3 \\
\hline $\mathrm{Fe}$ & 5.4 \\
\hline Th & 8.4 \\
\hline Other (Al, K, Na, Si) & 1.2 \\
\hline
\end{tabular}

together with the rest of the waste material not converted to $\mathrm{UF}_{6}$. Since the residue was re-fed to the flame reactor to reduce the amount of waste, thorium as well as other impurities were further concentrated in relation to uranium.

\section{Dissolution}

\section{Screening of lixiviants}

To identify the most promising lixiviant for the extraction of uranium from the waste material, a series of screening experiments was conducted using nitric, sulphuric, and hydrochloric acids at two concentrations, with and without addition of $\mathrm{H}_{2} \mathrm{O}_{2}$. Another objective was to determine whether the more water-soluble impurities could be removed during this step, even if uranium dissolution was not achieved. The results for the screening experiments in the absence of $\mathrm{H}_{2} \mathrm{O}_{2}$ are presented in Figure 1. The percentage dissolution of each element was calculated using the following relationship:

$$
\mathrm{E} \%=\frac{\mathrm{E}_{\text {solution }}}{\mathrm{E}_{\text {(solution + residue) }}} \times 100
$$

where E represents the specific element investigated.

It can be seen that the uranium dissolution was above $78 \%$ for all the acids, and $82 \%$ for water, with the highest

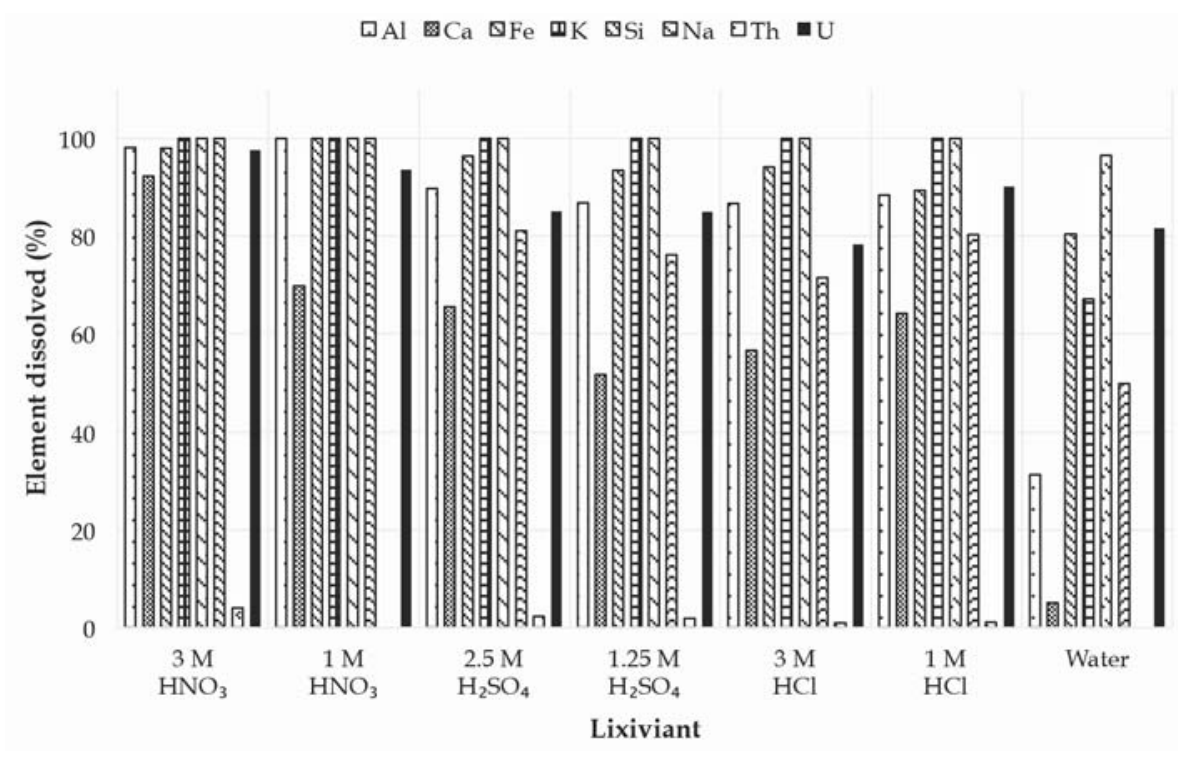

Figure 1-Effect of different lixiviants on the dissolution of various elements, in the absence of $\mathrm{H}_{2} \mathrm{O}_{2}$ 


\section{Recovery of uranium from nuclear conversion plant waste}

uranium recovery (98\%) observed in $3 \mathrm{M} \mathrm{HNO}_{3}$. It is noteworthy that the thorium concentration in solution remained below $5 \%$ in all instances. The solubility of calcium, however, was significantly different in in different acids, and very limited in water. Although the calcium content in the waste material could be due to a mixture of various compounds, the behaviour observed could be explained by the presence of calcium sulphate dihydrate $\left(\mathrm{CaSO}_{4} .2 \mathrm{H}_{2} \mathrm{O}\right)$, the solubility of which is $0.222 \mathrm{~g} / 100 \mathrm{~mL}$ in hot water and $0.241 \mathrm{~g} / 100 \mathrm{~mL}$ in cold water (CRC, 1976). Other calcium compounds show either very high or very low solubilities in water.

The solubility of $\mathrm{CaSO}_{4} \cdot 2 \mathrm{H}_{2} \mathrm{O}$ increases with an increase in acid concentration up to a maximum value (3.5 to $4.5 \mathrm{M}$ for $\mathrm{HNO}_{3}, 2.5$ to $3 \mathrm{M}$ for $\mathrm{HCl}$, and $1.5 \mathrm{M}$ for $\mathrm{H}_{2} \mathrm{SO}_{4}$ ), and then decreases if the acid concentration is increased further (Vershkova et al., 2003; Cameron and Breazeale, 1903; Ling and Demopoulos, 2004; Li and Demopoulos, 2005). For $\mathrm{H}_{2} \mathrm{SO}_{4}$, the initial increase in solubility of $\mathrm{CaSO}_{4} \cdot 2 \mathrm{H}_{2} \mathrm{O}$ has been attributed to the influence of the second dissociation constant of $\mathrm{H}_{2} \mathrm{SO}_{4}$, due to the higher solubility in the presence of $\mathrm{HSO}_{4}{ }^{-}$as well as to the increase in ionic strength in the presence of more $\mathrm{H}_{2} \mathrm{SO}_{4}$ (Marshall and Jones, 1966). The decrease in solubility at higher concentrations is believed to be due to a combination of effects which include changes in activity coefficient as well as salting-out due to the common-ion effect (Ling and Demopoulos, 2004; Calmanovici et al., 1993). The increasing and decreasing solubility in $\mathrm{HNO}_{3}$ was not clearly explained by Vershkova et al. (2003); however, Zhang et al. (2011) observed a decrease in the solubility of $\mathrm{CaSO}_{4} \cdot 2 \mathrm{H}_{2} \mathrm{O}$ in the order $\mathrm{HNO}_{3}>\mathrm{H}_{3} \mathrm{PO}_{4}>$ $\mathrm{H}_{2} \mathrm{SO}_{4}>\mathrm{Ca}\left(\mathrm{NO}_{3}\right)_{2}$, also without offering an explanation, but which agrees with the results we obtained. A possible explanation for the behaviour in $\mathrm{HCl}$ was given by $\mathrm{Li}$ and Demopoulos (2005), who ascribed the initial increase in solubility to the presence of $\mathrm{HSO}_{4}{ }^{-}$formed during dissolution of $\mathrm{CaSO}_{4} \cdot 2 \mathrm{H}_{2} \mathrm{O}$, and the decrease at higher $\mathrm{HCl}$ concentrations to the influence of ion activity coefficients.

While the values in Figure 1 cannot be compared directly with those from the literature, due to the complexity of this waste material, the above does explain the higher calcium extractions at higher $\mathrm{HNO}_{3}$ and $\mathrm{H}_{2} \mathrm{SO}_{4}$ concentrations. The lower calcium extraction at higher $\mathrm{HCl}$ concentration may indicate that the maximum $\mathrm{CaSO}_{4} \cdot 2 \mathrm{H}_{2} \mathrm{O}$ solubility was at a $\mathrm{HCl}$ concentration below $3 \mathrm{M}$.

The purities of the final uranium materials (calculated using Equation [1]) with regard to the three most prevalent impurities (Ca, Fe, and Th) are given in Table III. It is clear that both calcium (in acid) as well as iron (all acids and water) are nearly completely extracted during dissolution (see Table II for original concentrations). Some concentrations are higher than the original concentrations since the change in the amount of uranium extracted $(<100 \%)$ was used to calculate the percentage impurity.

As mentioned above, the calcium level was significantly lowered from 9.3 to $0.6 \%$ by dissolution in water. The amount of iron was higher in all instances, with smaller differences from the initial value in instances where uranium recovery was higher (e.g. $3 \mathrm{M} \mathrm{HNO}_{3}$ ). The reason for this is that iron was dissolved more completely compared to the other impurities (thorium was very insoluble, and calcium solubility depended on acid type and concentration). Therefore, since the impurity values are calculated in terms of the total amount of uranium present, the values for iron as an impurity would also be higher, especially if the uranium recovery is lower. A more in-depth discussion on the behaviour of iron follows in the next section. The amount of thorium was lowered so significantly in all instances that all lixiviants are suitable for the separation of uranium and thorium during the dissolution step.

\section{Influence of $\mathrm{H}_{2} \mathrm{O}_{2}$}

The influence of $\mathrm{H}_{2} \mathrm{O}_{2}$ on the recovery of uranium in water and different acids at various concentrations, as well as on the purity of the final uranium solution, was determined. $\mathrm{H}_{2} \mathrm{O}_{2}$ acts as an oxidizing agent to facilitate the oxidation of the insoluble $\mathrm{U}(\mathrm{IV})$ to more soluble $\mathrm{U}(\mathrm{VI})$. The influence of $\mathrm{H}_{2} \mathrm{O}_{2}$ on the amount of impurities extracted, as well as the uranium recoveries for the different lixiviants, is presented in Figure 2.

The secondary y-axis gives the difference in uranium recoveries in the absence and presence of $\mathrm{H}_{2} \mathrm{O}_{2}$. Therefore, a large positive value indicates a large increase in uranium recovery when $\mathrm{H}_{2} \mathrm{O}_{2}$ is added and a value of zero, no difference. The influence of $\mathrm{H}_{2} \mathrm{O}_{2}$ on uranium recovery was greatest when using $3 \mathrm{M} \mathrm{HCl}$. In contrast, the influence of $\mathrm{H}_{2} \mathrm{O}_{2}$ was negligible when using $\mathrm{HNO}_{3}$ and $2.5 \mathrm{M} \mathrm{H}_{2} \mathrm{SO}_{4}$. This can be explained in terms of the oxidizing ability of these acids. The standard electrode potentials (Table IV) show that $\mathrm{HNO}_{3}$ is the stronger oxidizing agent, whereas the oxidizing ability of $\mathrm{H}_{2} \mathrm{SO}_{4}$, increases at higher acid concentrations, hence the diminished influence of $\mathrm{H}_{2} \mathrm{O}_{2}$ in the more concentrated $\mathrm{H}_{2} \mathrm{SO}_{4}$ solution. However, the influence of $\mathrm{H}_{2} \mathrm{O}_{2}$, which was high with $3 \mathrm{M} \mathrm{HCl}$, decreased again at the lower $\mathrm{HCl}$ concentration, and was low in water.

The bar chart (primary y-axis) in Figure 2 shows the effect of $\mathrm{H}_{2} \mathrm{O}_{2}$ on the impurity level of the final uranium solution, taking into account all elements and using Equation [1]. For the percentage impurity extraction in the absence of $\mathrm{H}_{2} \mathrm{O}_{2}$, the combined totals of the values presented in Table III were used. It is clear that the presence of $\mathrm{H}_{2} \mathrm{O}_{2}$ had little influence on extraction of impurities. The purity of the solution increased slightly for $\mathrm{HNO}_{3}, \mathrm{HCl}$, and water while decreasing slightly for $\mathrm{H}_{2} \mathrm{SO}_{4}$ in the presence of $\mathrm{H}_{2} \mathrm{O}_{2}$.

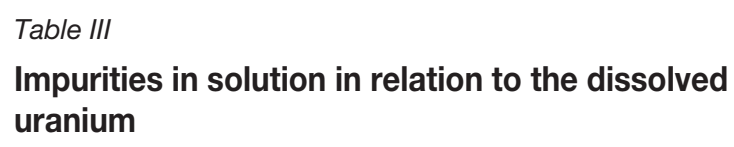

\begin{tabular}{|l|c|c|c|c|}
\hline Method & $\mathrm{Ca}(\%)$ & $\mathrm{Fe}(\%)$ & Th (\%) & Other (\%) \\
\hline Initial & 9.3 & 5.3 & 8.3 & 1.3 \\
$3 \mathrm{M} \mathrm{HNO}_{3}$ & 9.6 & 5.5 & 0.6 & 5.4 \\
$1 \mathrm{M} \mathrm{HNO}_{3}$ & 6.6 & 5.7 & 0.1 & 4.2 \\
$2.5 \mathrm{M} \mathrm{H}_{2} \mathrm{SO}_{4}$ & 8.1 & 6.1 & 0.3 & 3.4 \\
$1.25 \mathrm{M} \mathrm{H}_{2} \mathrm{SO}_{4}$ & 5.8 & 5.3 & 0.2 & 3.6 \\
$3 \mathrm{M} \mathrm{HCl}$ & 6.9 & 5.8 & 0.1 & 3.7 \\
$1 \mathrm{M} \mathrm{HCl}$ & 8.5 & 6.7 & 0.1 & 3.5 \\
Water & 0.6 & 6.2 & 0.1 & 4.0 \\
\hline
\end{tabular}




\section{Recovery of uranium from nuclear conversion plant waste}

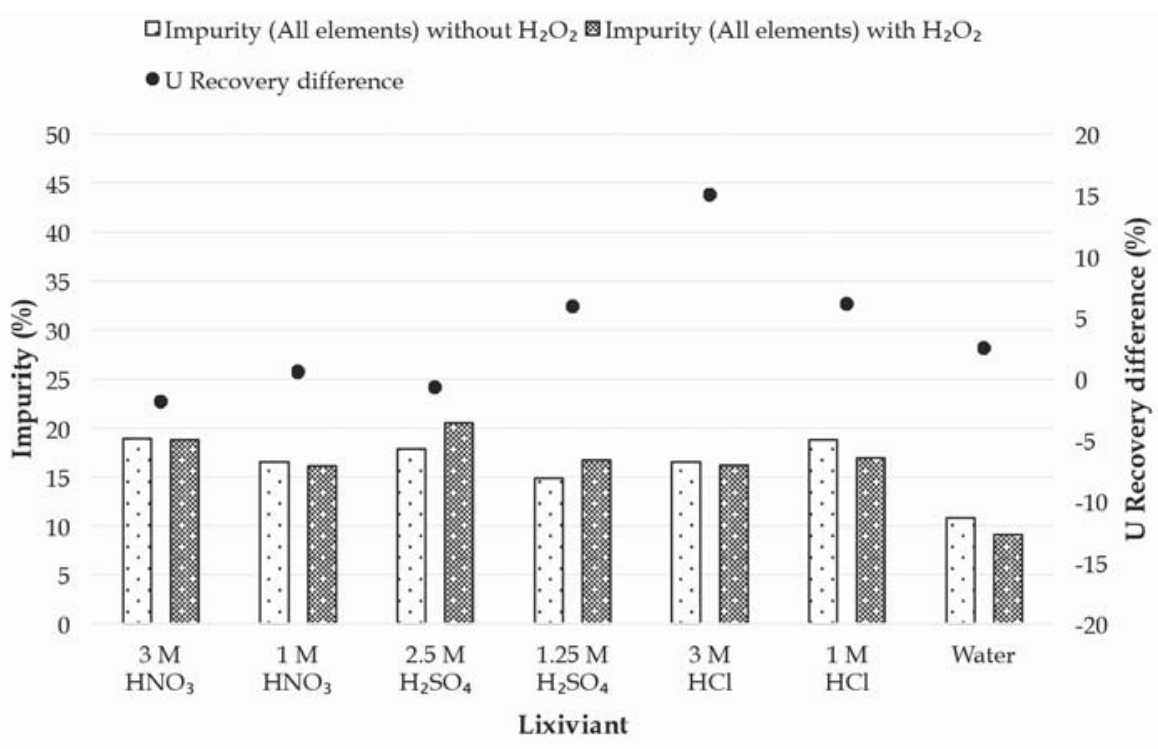

Figure 2-Influence of $\mathrm{H}_{2} \mathrm{O}_{2}$ on uranium recovery and purity of the solution

\begin{tabular}{|c|c|c|}
\hline \multicolumn{3}{|c|}{$\begin{array}{l}\text { Table IV } \\
\text { Standard electrode potentials of acids and metals under } \\
\text { investigation (CRC, 1976) }\end{array}$} \\
\hline \multirow[t]{2}{*}{ Medium/ metal } & Equlibrium reaction & $E^{0}(\mathrm{~V})$ \\
\hline & More oxidizing & \\
\hline $\mathrm{H}_{2} \mathrm{O}_{2}$ & $\mathrm{H}_{2} \mathrm{O}_{2}+2 \mathrm{H}^{+}+2 \mathrm{e}^{-} \rightarrow 2 \mathrm{H}_{2} \mathrm{O}$ & +1.77 \\
\hline $\mathrm{HCl}$ & $\mathrm{Cl}_{2(\mathrm{o})}+2 \mathrm{e} \rightarrow 2 \mathrm{Cl}_{(2 \mathrm{~g})}$ & +1.36 \\
\hline \multirow[t]{2}{*}{$\mathrm{HNO}_{3}$} & $\mathrm{NO}_{3(\mathrm{aq})}^{-}+4 \mathrm{H}_{(\mathrm{aq})}^{+}+3 \mathrm{e}^{-} \rightarrow \mathrm{NO}_{2(\mathrm{~g})}+2 \mathrm{H}_{2} \mathrm{O}$ & +0.96 \\
\hline & $\mathrm{NO}_{3(\mathrm{aq})}^{-}+3 \mathrm{H}_{(\mathrm{aq})}^{+}+3 \mathrm{e} \rightarrow \mathrm{HNO}_{2(\mathrm{aq})}+2 \mathrm{H}_{2} \mathrm{O}$ & +0.94 \\
\hline Ferric & $\mathrm{Fe}_{(\mathrm{aq})}^{3+}+\mathrm{e}^{-} \rightarrow \mathrm{Fe}^{2+}$ & +0.77 \\
\hline Uranium & $\mathrm{UO}_{2(\text { aq) }}^{2+}+4 \mathrm{H}^{+}+\mathrm{e}^{-} \rightarrow \mathrm{U}^{4+}+2 \mathrm{H}_{2} \mathrm{O}$ & +0.273 \\
\hline \multirow[t]{2}{*}{$\mathrm{H}_{2} \mathrm{SO}_{4}$} & $\mathrm{SO}_{4(\mathrm{aq})}{ }^{2}+4 \mathrm{H}^{+} \rightarrow \mathrm{SO}_{2(\mathrm{~g})}+2 \mathrm{H}_{2} \mathrm{O}$ & +0.2 \\
\hline & $\mathrm{SO}_{4(\mathrm{aq})}{ }^{2-}+4 \mathrm{H}^{+} \rightarrow \mathrm{H}_{2} \mathrm{SO}_{3(\mathrm{~g})}+\mathrm{H}_{2} \mathrm{O}$ & +0.17 \\
\hline Hydrogen & $2 \mathrm{H}^{+}{ }_{(\mathrm{aq})}+2 \mathrm{e}^{-} \rightarrow \mathrm{H}_{2(\mathrm{~g})}$ & 0.00 \\
\hline Ferrous & $\mathrm{Fe}^{2+}{ }_{(\mathrm{aq})}^{2+1}+2 \mathrm{e}^{-} \rightarrow \mathrm{Fe}_{(\mathrm{s})}$ & -0.44 \\
\hline Water & $2 \mathrm{H}_{2} \mathrm{O}_{(D)}+2 \mathrm{e}^{-} \rightarrow \mathrm{H}_{2(\mathrm{~g})}+2 \mathrm{OH}_{(\mathrm{aq})}$ & -0.8227 \\
\hline \multicolumn{3}{|c|}{ More reducing } \\
\hline
\end{tabular}

As regards the three most abundant impurities ( $\mathrm{Ca}, \mathrm{Fe}$, and $\mathrm{Th}$ ), most of the thorium had already been removed in the absence of $\mathrm{H}_{2} \mathrm{O}_{2}$ (Table IV), and thorium removal was not further improved by adding $\mathrm{H}_{2} \mathrm{O}_{2}$. The effect of $\mathrm{H}_{2} \mathrm{O}_{2}$ on the dissolution of calcium and iron is shown in Figure 3.

The reason for the decrease in solution purity for $\mathrm{H}_{2} \mathrm{SO}_{4}$ in the presence of $\mathrm{H}_{2} \mathrm{O}_{2}$ (Figure 2) becomes clear from Figure 3 , which shows higher amounts of calcium and, in certain instances, iron dissolved. The increase in calcium dissolution may be due to a reaction between calcium and $\mathrm{H}_{2} \mathrm{O}_{2}$ that results in the formation of a more acid-soluble calcium species such as calcium peroxide $\left(\mathrm{CaO}_{2}\right)$ (Tsentsiper and Vasil'eva, 1967). At present, it is not viewed as critical to the uranium recovery aspect of this study for this aspect to be investigated further. Furthermore, a decrease in the amount of iron dissolved in water was observed when $\mathrm{H}_{2} \mathrm{O}_{2}$ is added.
The influence of $\mathrm{H}_{2} \mathrm{O}_{2}$ on iron is unexpected since the purpose of $\mathrm{H}_{2} \mathrm{O}_{2}$ addition was to interact with $\mathrm{U}(\mathrm{IV})$. The influence of $\mathrm{H}_{2} \mathrm{O}_{2}$ on uranium recovery in water (Figure 2) was also surprisingly low, since water is not a particularly oxidizing environment (see Table IV) and it was expected that $\mathrm{H}_{2} \mathrm{O}_{2}$ would increase uranium recovery in water.

The observations thus far suggest that the oxidizing ability of each lixiviant, the presence of $\mathrm{H}_{2} \mathrm{O}_{2}$, and the iron present in the waste material influence each other, thereby influencing the recovery of both uranium and impurities. $\mathrm{Fe}^{3+}$ is known to oxidize insoluble $\mathrm{U}(\mathrm{IV})$ to soluble $\mathrm{U}(\mathrm{VI})$ (Ervanne, 2004; Venter and Boylett, 2009) while being reduced to $\mathrm{Fe}^{2+}$ according to the following simplified equation:

$$
\mathrm{U}(\mathrm{IV})+2 \mathrm{Fe}^{3+} \rightarrow \mathrm{U}(\mathrm{VI})+2 \mathrm{Fe}^{2+}
$$




\section{Recovery of uranium from nuclear conversion plant waste}

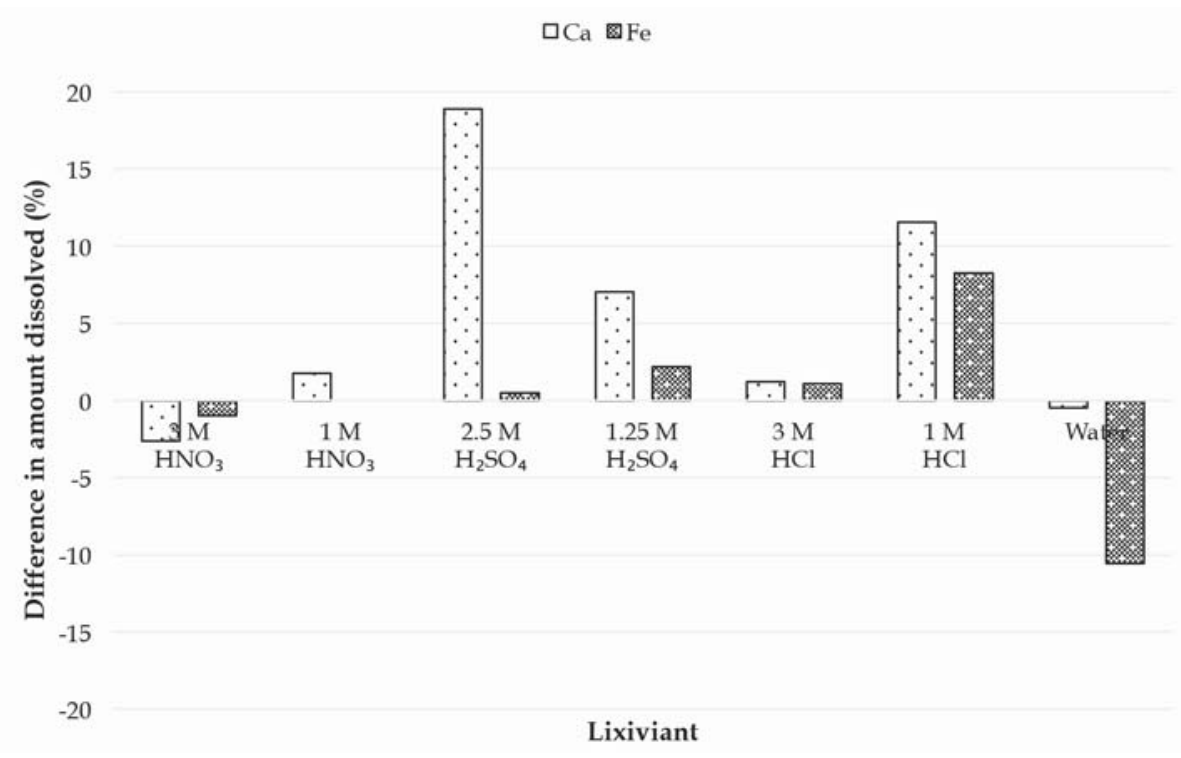

Figure 3-Influence of $\mathrm{H}_{2} \mathrm{O}_{2}$ on the amounts of $\mathrm{Ca}$ and $\mathrm{Fe}$ in solution

Since iron is present in the waste material in significant amounts, it may be possible that the oxidative dissolution of uranium is facilitated by $\mathrm{Fe}^{3+}$ and not directly by $\mathrm{H}_{2} \mathrm{O}_{2}$ as initially thought. In the presence of a strongly oxidizing acid such as $\mathrm{HNO}_{3}$, which is a stronger oxidizer than $\mathrm{Fe}^{3+}$ (Table IV), the oxidation of U(IV) is facilitated mostly by the acid itself and the effect of iron is masked. The $\mathrm{H}_{2} \mathrm{O}_{2}$ then rather acts as an oxidizing agent to regenerate the formed $\mathrm{Fe}^{2+}$ back to $\mathrm{Fe}^{3+}$, which is then again available to oxidize $\mathrm{U}(\mathrm{IV})$, as also described by Venter and Boylett (2009) for uranium leaching. The reaction of $\mathrm{Fe}^{2+}$ with $\mathrm{H}_{2} \mathrm{O}_{2}$ in the presence of acid can be represented by the following equation:

$$
2 \mathrm{Fe}^{2+}+\mathrm{H}_{2} \mathrm{O}_{2}+2 \mathrm{H}^{+} \rightarrow 2 \mathrm{Fe}^{3+}+2 \mathrm{H}_{2} \mathrm{O}
$$

The higher uranium recovery in the presence of $\mathrm{H}_{2} \mathrm{O}_{2}$ with the lower concentration of $\mathrm{H}_{2} \mathrm{SO}_{4}$ can be explained by the lower oxidizing capability of $\mathrm{H}_{2} \mathrm{SO}_{4}$ at lower concentrations and its lower oxidizing capability compared with $\mathrm{Fe}^{3+}$, as seen in Table IV. Therefore, the $\mathrm{Fe}^{2+}$ formed during oxidation of $\mathrm{U}(\mathrm{IV})$ can be re-oxidized by $\mathrm{H}_{2} \mathrm{O}_{2}$ to $\mathrm{Fe}^{3+}$, which will in turn enhance the uranium recovery. A similar effect was observed in $3 \mathrm{M} \mathrm{HCl}$ and since this is the least oxidizing environment, the addition of $\mathrm{H}_{2} \mathrm{O}_{2}$ yielded the greatest enhancement of uranium recovery. The decrease in iron dissolution in water when $\mathrm{H}_{2} \mathrm{O}_{2}$ is added may indicate the formation of an insoluble iron species, the nature of which is unknown and which would have to be further investigated.

\section{Influence of $\mathrm{HNO}_{3}$ concentration}

In the initial tests the highest uranium recovery was achieved in $\mathrm{HNO}_{3}$. In addition, when using $\mathrm{HNO}_{3}$ systems, the addition of $\mathrm{H}_{2} \mathrm{O}_{2}$ did not improve uranium recovery, while impurities such as iron had less of an influence on uranium recovery. To further optimize the dissolution, higher concentrations of $\mathrm{HNO}_{3}$ were used to confirm the observations made during the screening, where only two values in the lower concentration range were included. For this purpose the effect of $\mathrm{HNO}_{3}$ concentrations from $1 \mathrm{M}$ to $12 \mathrm{M}$ on the uranium recovery, as well as on the purity of the final solution, was investigated. The values for all elements dissolved in the different $\mathrm{HNO}_{3}$ concentrations are presented in Figure 4, calculated similarly as in Figure 1.

The recovery of uranium in $\mathrm{HNO}_{3}$ initially increased with increasing acid concentration, reaching a maximum of $98 \%$ at $3 \mathrm{M}$ before declining to $78.75 \%$ in $12 \mathrm{M} \mathrm{HNO}_{3}$. Currently, there is no explanation for this decrease in recovery at higher $\mathrm{HNO}_{3}$ concentrations, and further investigation is needed.

Calcium dissolution increased with increasing $\mathrm{HNO}_{3}$ concentration, from $69.83 \%$ at $1 \mathrm{M}$ to $92.3 \%$ at $3 \mathrm{M}$, followed by a slight decrease to $88.05 \%$ at $6 \mathrm{M}$ and then decreasing significantly to $63.03 \%$ at $12 \mathrm{M} \mathrm{HNO}_{3}$. These observations again agree with results in the literature in terms of the solubility of $\mathrm{CaSO}_{4} \cdot 2 \mathrm{H}_{2} \mathrm{O}$ in $\mathrm{HNO}_{3}$, where an increase is observed with increasing acid concentration up to a certain point, followed by a decrease at higher concentrations (Vershkova et al., 2003). The amount of $\mathrm{Ca}, \mathrm{Fe}, \mathrm{Th}$, and other impurities dissolved in relation to the amount of uranium dissolved was calculated using Equation [1], and the results are presented in Table V. Again, the thorium impurity was lowered from $8.4 \%$ to $<1 \%$ irrespective of the $\mathrm{HNO}_{3}$ concentration. The amount of iron increased in all $\mathrm{HNO}_{3}$ concentrations, with the lowest value at $3 \mathrm{M}$. For calcium, the lowest impurity levels were attained at $1 \mathrm{M}$ and at $12 \mathrm{M}$, with the highest impurities at $6 \mathrm{M}$. The lowest total impurity level was obtained at $1 \mathrm{M} \mathrm{HNO}_{3}$.

\section{Influence of $\mathrm{H}_{2} \mathrm{O}_{2}$ in $\mathrm{HNO}_{3}$}

The results obtained when studying the influence of $\mathrm{H}_{2} \mathrm{O}_{2}$ in $\mathrm{HNO}_{3}$ on uranium recovery and the purity of the final solution can be seen in Figure 5. The values of the bar chart (primary y-axis) represent the percentage impurity of the final solution calculated from all elements. The secondary yaxis shows the difference between the uranium recoveries in the absence and presence of $\mathrm{H}_{2} \mathrm{O}_{2}$. 


\section{Recovery of uranium from nuclear conversion plant waste}

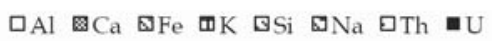

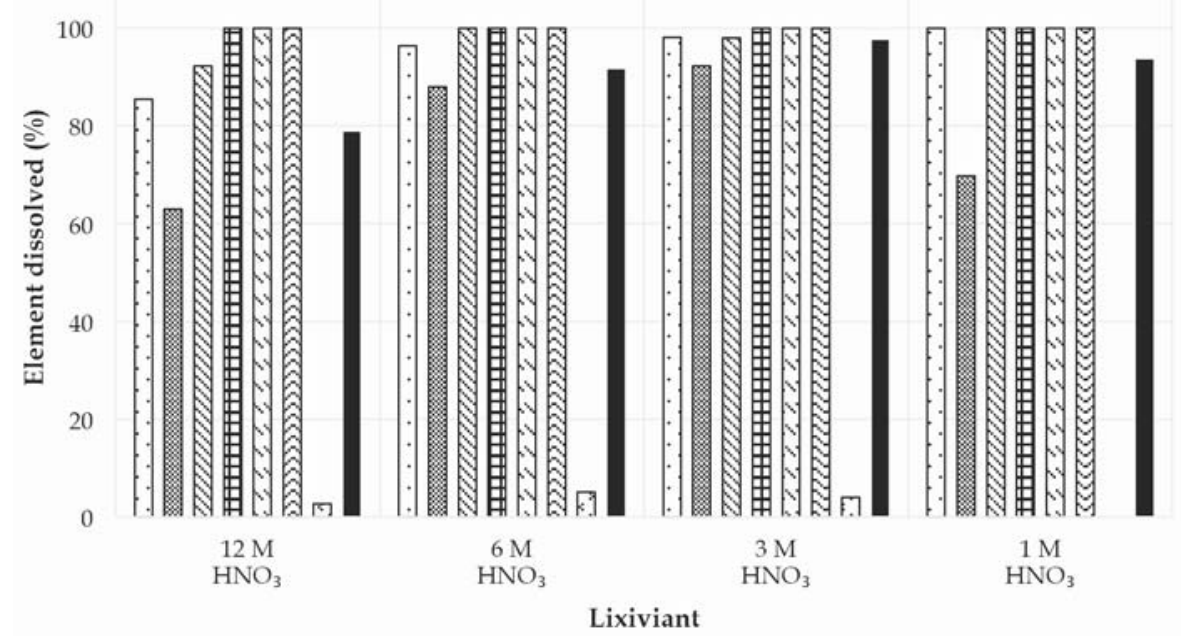

Figure 4-Dissolution of each element in different concentrations of $\mathrm{HNO}_{3}$ in the absence of $\mathrm{H}_{2} \mathrm{O}_{2}$

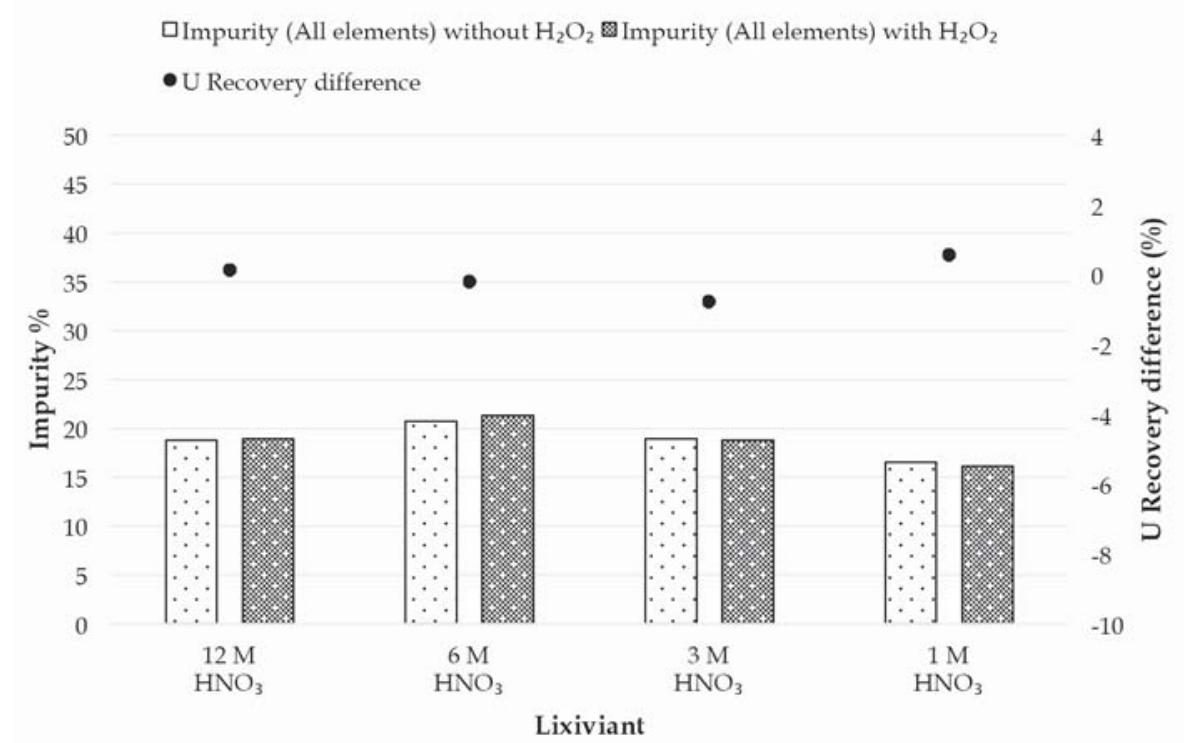

Figure 5-Impurity of the solution in relation to uranium (including all elements present) and difference in uranium recovery in the presence of $\mathrm{H}_{2} \mathrm{O}_{2}$

\begin{tabular}{|c|c|c|c|c|}
\hline \multicolumn{5}{|c|}{$\begin{array}{l}\text { Impurities in solution in relation to uranium as a } \\
\text { function of } \mathrm{HNO}_{3} \text { concentration }\end{array}$} \\
\hline Method & $\mathrm{Ca}(\%)$ & $\mathrm{Fe}(\%)$ & Th (\%) & Other (\%) \\
\hline Initial & 9.3 & 5.3 & 8.4 & 1.3 \\
\hline $12 \mathrm{M} \mathrm{HNO}_{3}$ & 8.5 & 6.6 & 0.4 & 3.3 \\
\hline $6 \mathrm{M} \mathrm{HNO}_{3}$ & 10.6 & 6.2 & 0.5 & 3.0 \\
\hline $3 \mathrm{M} \mathrm{HNO}_{3}$ & 9.6 & 5.5 & 0.6 & 5.4 \\
\hline $1 \mathrm{M} \mathrm{HNO}_{3}$ & 6.6 & 5.7 & 0.1 & 4.1 \\
\hline
\end{tabular}

These results confirm the observations from the screening tests, in that $\mathrm{H}_{2} \mathrm{O}_{2}$ has limited influence on uranium recovery in an $\mathrm{HNO}_{3}$ environment and an insignificant influence on the purity of the final solution. Therefore, $\mathrm{HNO}_{3}$ would be an ideal choice for dissolution of the waste material, after which further purification will be conducted.

\section{Conclusions}

The nuclear conversion plant waste material is soluble in different acids. Different uranium recoveries were obtained at different acid concentrations, with the highest recovery (98\%) being obtained in $3 \mathrm{M} \mathrm{HNO}_{3}$. Furthermore, for $3 \mathrm{M}$ 


\section{Recovery of uranium from nuclear conversion plant waste}

$\mathrm{HNO}_{3}$, it was not necessary to add an oxidizing agent to increase the uranium recovery or to decrease impurity levels. An advantage of all lixiviants studied is that thorium was largely removed from the waste material, decreasing from $8.4 \%$ to less than $1 \%$ in relation to the extracted uranium. The waste material was also leachable in water, with $82 \%$ uranium recovery combined with a significant reduction in the total amount of impurities in relation to uranium (from $24.3 \%$ to $10.8 \%$ ).

The influence of $\mathrm{H}_{2} \mathrm{O}_{2}$ on uranium recovery was found to be greatest in less oxidizing environments, especially in $3 \mathrm{M}$ $\mathrm{HCl}$. This is probably due to the role of $\mathrm{Fe}^{3+}$ as an oxidizing agent for the oxidative dissolution of $\mathrm{U}(\mathrm{IV}), \mathrm{Fe}^{3+}$ being in turn reduced to $\mathrm{Fe}^{2+}$. The $\mathrm{H}_{2} \mathrm{O}_{2}$ then acts to regenerate $\mathrm{Fe}^{2+}$ to $\mathrm{Fe}^{3+}$, which is once again available for oxidation of $\mathrm{U}(\mathrm{IV})$. In view of the significant amounts of fluoride present in the waste material, future work to will investigate suitable methods for fluoride removal.

Due to the environmental liability around the conversion plant waste material, successful dissolution thereof opens up possibilities for re-use of the material once the uranium has been purified. Not only will the amount of waste in storage be reduced, but a valuable product will be obtained that may possibly be used as feed material to a conversion process.

\section{Acknowledgements}

We would like to thank the National Research Foundation (NRF), the Nuclear Energy Corporation of South Africa (Necsa), and the Chemical Resource Beneficiation (CRB) group for funding that made this work possible. We would also like to acknowledge Mr L. Nkadimeng for help with experimental work.

\section{References}

ASTM. 2013. Standard specification for uranium ore concentrate. 3. ASTM International, West Conshohocken, PA.

CAlmanovici, C.E., Gabas, N., and LAguérIE, C. 1993. Solubility measurements for calcium sulfate dihydrate in acid solutions at 20,50 and $70^{\circ} \mathrm{C}$. Journal of Chemical Engineering and Data, vol. 38. pp. 534-536.

Cameron, F.K. and Breazeale, J.F. 1903. Solubility of calcium sulphate in aqueous solutions of sulphuric acid. Journal of Physical Chemistry, vol. 7. pp. 271-577.

Coleman, C.F. 1966. Recovery of uranium and zirconium from aqueous fluoride solutions. US patent US3243257.

CRC. 1976. Handbook of Chemistry and Physics. CRC Press, Boca Raton, FL.

ERvanNe, H. 2004. Detecting and minimizing interferences in uranium oxidation states during dissolution of solid phases. Journal of Radioanalytical and Nuclear Chemistry, vol. 260. pp. 249-253.

FLoREANCIG, A. 1983. Method of dissolving impure uranium tetrafluoride. France patent application.

Kumar, J.R., KIm, J.-S., LeE, J.-Y., and Yoon, H.-S. 2011. A brief review on solvent extraction of uranium from acidic solutions. Separation and Purification Reviews, vol. 40. pp. 77-125.

Li, Z. and Demopoulos, G.P. 2005. Solubility of $\mathrm{CaSO}_{4}$ phases in aqueous $\mathrm{HCl}+$ $\mathrm{CaCl}_{2}$ solutions from $283 \mathrm{~K}$ to $353 \mathrm{~K}$. Journal of Chemical and Engineering Data, vol. 50. pp. 1971-1982.

Ling, Y. and Demopoulos, G.P. 2004. Solubility of calcium sulfate hydrates in (0 to 3.5) mol.kg-1 sulfuric acid solutions at $100^{\circ} \mathrm{C}$. Journal of Chemical and Engineering Data, vol. 49. pp. 1263-1268.

LuK'YANCHEv, Y. and NiKoLAEv, N.S. 1963. The solubility of uranium tetrafluoride in aqueous solutions of acids. Atomic Energy, vol. 15. pp. 1184-1187.

MARShAlL, W.L. and Jones, E.V. 1966. Second dissociation constant of sulfuric acid from 25 to $350^{\circ}$ evaluated from solubilities of calcium sulfate in sulfuric acid solutions. Journal of Physical Chemistry, vol. 70. pp. 4028-4040.

OHASHI, Y., Murashita, S., and Nomura, M. 2014. Extraction of uranium from solid waste containing uranium and fluorine. Minerals Engineering, vol. 61. pp. 32-39.

Ponelis, A.A. 1989. Die invloed van alkali-metaalonsuiwerhede op die uraandioksiedhidrofluorineringsreaksie. $\mathrm{PhD}$ thesis, University of Pretoria.

Ponelis, A.A., Slabber, M.N., and Zimmer, C.H.E. 1986. Conversion of nonnuclear grade feedstock to $\mathrm{UF}_{4}$. Proceedings of Advances in Uranium Refining and Conversion. International Atomic Energy Agency, Vienna. pp. 111-139.

SASAHIRA, A., Kani, Y., Iino, K., Hoshino, K., and Kawamura, F. 2007. Development of FLUOREX process as a progressive LWR reprocessing system. Proceedings of the Global 2007 Conference on Advanced Nuclear Fuel Cycles and Systems, Boise, Idaho, 9-13 September 2007. American Nuclear Society, La Grange Park, IL

TSENTSIPER, A.B. and VASIL'EVA, R.P. 1967. The reaction of calcium hydroxide with hydrogen peroxide vapor. Bulletin of the Academy of Sciences of the USSR, Division of Chemical Science, vol. 16. pp. 2445-2447.

Venter, R. and Boylett, M. 2009. The evaluation of various oxidants used in acid leaching of uranium. Proceedings of Hydrometallurgy 2009. Southern African Institute of Mining and Metallurgy, Johannesburg. pp. 445-255.

VershKova, Y.A., Tareeva, O.A., Ivlev, K.G.M., and LoKshin, E.P. 2003. Solubility of calcium sulfate dihydrate in nitric acid at $20^{\circ} \mathrm{C}$. Russian Journal of Applied Chemistry, vol. 76. pp. 156-157.

Volk, V.I., VAKhrushin, A.Y., and Mamaev, S.L. 2000. Extraction of uranium and thorium with TBP from fluoride - nitric acid solutions. Journal of Radioanalytical and Nuclear Chemistry, vol. 246. pp. 697-702.

Zhang, Q.Y., Huang, X.H., TANG, H.B., and HE, H. 2011. Electrochemical behavior of uranium(VI) in 1-butyl-3-methylimidazolium chloride. HeHuaxue yu Fangshe Huaxue (Journal of Nuclear and Radiochemistry), vol. 33. pp. 101-105. 